\title{
THE ROLE OF GOVERNMENT INSTITUTIONS IN SUPPORTING THE PRESERVATION OF GLOBAL AND LOCAL HERITAGE CITIES A COMPARATIVE STUDY (HISTORIC CAIRO - ALEXANDRIA)
}

\author{
Muhammad Atef Abu Ashour*
}

Architectural Engineering Department, Faculty of Engineering, Zagazig University, Egypt

\begin{abstract}
Heritage is one of the most important products of civilizations that express the development of peoples, societies and peoples throughout history, and it expresses the capabilities that man has reached, and this is not limited to language, literature and thought only, but it pervades all the material and emotional elements of society such as thought, philosophy, religion, science, art and architecture. Urbanism is considered one of the most essential elements of the heritage and is distinguished from other heritage elements by its material existence. Again, the existence of civilizations of previous generations is like the memory of the nation. It also highlights the succession of intergenerational civilizational, social and religious experiences and values.

Keywords

GOVERNMENT INSTITUTIONS- PRESERVATION-HERITAGE CITIES- HISTORIC CAIRO-ALEXANDRIA
\end{abstract}

\section{Introduction}

Society is the womb of architecture and urbanism, the built environment is the product of an intellectual interaction between individuals and groups of any society, and it is the result of the convictions of that community that produces this urban environment. The city, especially the mega-cities, has its own environment according to its characteristics, location, position, shape of its urban fabric, and the various economic and service activities within the urban fabric. As well as creating open outdoor spaces in its fabric and the activities of the people that, constitute the biosphere and the contents of the city.

The historical city of Cairo is an urban model born according to the standards and the Islamic view of life, enriched by the multiplicity of cultures coming to all the peoples that I shade as the banner of Islam, so it came as a unique model of its kind in the history of human architecture, and an urban pattern that reflects the cultures of those peoples and their previous methods of dealing with forms and bodies and their suitability for jobs Social, spiritual, economic, political and climatic conditions, as well as solutions to the problems that faced the Islamic human community. We also note that the monuments of historical Cairo are identifiers of the city, representing gathering points or directives that cannot be absent from one's mind in his perception and awareness of the urban area and what it was in the past.

Also, what distinguishes the civilizational heritage of Historic Cairo is the statement and clarity of the continuity of the great construction activities over several centuries (from approximately 9111 AD to 9011 years). He gave very great importance to the cultural and archaeological attraction of the historic city.

The civilizational significance of Historic Cairo is recognized by the countries of the world, as the Old City is on the list of world heritage that was prepared by the World Heritage Conference in the year 9191 AD under the name of "Islamic Cairo", in recognition of its absolute historical, archaeological and urban importance. As this national capital has been subjected to multiple violations throughout the ages as a result of looting at other times, neglect at other times and the encroachment of organic urbanism at other times, in addition to many other environmental and natural influences and factors (such as winds, groundwater, environmental and seasonal differences, temperatures, high direct and widespread solar radiation and soil instability. And increase the rate of air pollution and others. (For many times, these urgent heritage problems were not dealt with in proportion to their importance, which led to the expansion of the rates of erosion, demolition, decomposition and disintegration of the Islamic heritage in the heart of the urban cluster of the historic city of Cairo.

On the other hand, other attempts appeared on the part of the Egyptian government represented by the Supreme Council of Antiquities and the University of Alexandria in cooperation with UNESCO (to preserve the heritage of the city of Alexandria and to emphasize the revival of the ancient library and on top of the selected areas to preserve three important heritage sites very close to each other, where One of them is found on land and the other is in shallow waters, the Qala Qaytaei, which dates back to the fifteenth century AD, rises tall in the

\footnotetext{
* Corresponding author: Mohamed.atf@gmail.com
} 
eastern port, and the remains of the ancient lighthouse of Alexandria lie opposite the castle in the sea, while the ruins of the Ptolemaic royal quarter are inundated with the waters of the eastern port.

The preservation of these sites requires an integrated approach in order to preserve these three sites and ultimately open them as a museum to the public and researchers.

\section{Heritage concept:}

There are many definitions that dealt with the concept of urban heritage, perhaps the most famous of which is ICOMOS International Council on Monuments and Sites - a global non-governmental organization concerned with preserving the urban heritage, and it is an offshoot of UNESCO - which defined heritage as: all human constructions from cities, villages and neighborhoods Historical or cultural.

locally:

Egypt officially defined heritage through Law No. 999 for the Protection of Antiquities for the year $9102 \mathrm{AD}$ and its amendments, considering that the antiquity is every real estate or movable produced by different civilizations or brought about by the arts, sciences, literature and religions from the prehistoric era and through the successive historical eras until a hundred years ago when it has an archaeological value or significance Or historical, as it is a manifestation of the various civilizations that were established on the land of Egypt or had a historical connection to it, as well as the remains of human dynasties and their contemporary creatures.

Globally:

World Heritage sites are landmarks that are nominated by the UNESCO World Heritage Committee to be included in the international heritage sites program managed by UNESCO. These features may be natural, such as forests and mountain ranges, or they may be man-made, such as buildings and cities, or they may be mixed.

\section{Local Heritage Management Institutions:}

\section{First: monuments buildings:}

Antiquities Law No. 999 for the year 9102 in clause (5) specified that the Supreme Council of Antiquities is the main department for supervising everything related to antiquities affairs, starting from museums and their movable and stored antiquities to archaeological and historical sites and areas, even if they are found by chance. Responsibilities go up from the Supreme Council of Antiquities to the relevant permanent committee or the board of directors of the relevant museum, to the Minister of Culture, then to the Prime Minister, and they are submitted to the President of the Republic if necessary.

\section{Second: buildings and areas of value:}

It is managed by the following institutions:

The National Organization for Urban Coordination:

It is concerned with directing and controlling urban development, preserving the distinctive heritage urban balance, as well as laying general foundations for dealing with buildings of architectural and urban value dating back to the nineteenth and early twentieth centuries, and other buildings that were not registered as antiquities, and therefore they are not subject to Law 111 of 1891 . Concerning the protection of antiquities, but they apply the standards and specifications stipulated in Law 111 of 0226 in the matter of organizing the demolition of buildings and structures that are not prone to fall and preserving the architectural heritage, and in the Prime Minister's Decree No. 2016 of 2016 (Guide to the National Authority for Urban Coordination, the Ministerial Committee to Supervise Implementation of the project to develop historic Cairo.

\section{Suggested results:}

From the above, it is clear that there are deficiencies in the preservation management policies followed in managing Egyptian heritage cities in general as a result of many factors, the most important of which are:

.1The huge financial needs of these regions, and the direction of spending priorities for development and service projects.

.2In many cases, the absence of binding governmental institution legislation was one of those factors affecting the preservation policies of heritage cities in Egypt.

.3The scarcity of disciplines concerned with the matter of preserving and protecting historic cities.

.4Loss of archaeological awareness among individuals and some governments in previous eras.

.5Social and economic pressures, and poor infrastructure.

\section{Recommendations:}

-1Historic Cairo as a representative of the world heritage: 


\section{THE ROLE OF GOVERNMENT INSTITUTIONS IN SUPPORTING THE PRESERVATION OF GLOBAL AND LOCAL HERITAGE CITIES A COMPARATIVE STUDY (HISTORIC CAIRO - ALEXANDRIA)}

According to the previous analysis of the Historic Cairo site, we can add a number of proposals for the preservation of Historic Cairo as a world heritage site, within the framework of a balanced and integrated action plan for the entire region at the level of construction and not only at the level of antiquities, as follows:

Prepare a conservation plan for the property and the buffer zone for protection, including the management plan required by the guidelines for implementing the World Heritage Convention.

Creating a risk map for historic Cairo to determine implementation priorities and define a priority work area, and an action plan for implementing the conservation strategy in that area.

Reviewing, updating and completing the existing legislation related to the preservation of the architectural and urban heritage, planning and public works, in order to provide an appropriate legal framework while ensuring that legislation does not conflict.

-Establishing an appropriate and common information base for urban conservation and setting up an appropriate institutional framework to implement an urban conservation policy for Historic Cairo, with the ability to implement and improve cooperation between the various governmental agencies and the participating and relevant institutions.

-Developing programs to help the poor to provide job opportunities through the project of rehabilitating historic Cairo, as well as supporting work to revive and support local crafts and invest them, and to support cultural trade

\section{References}

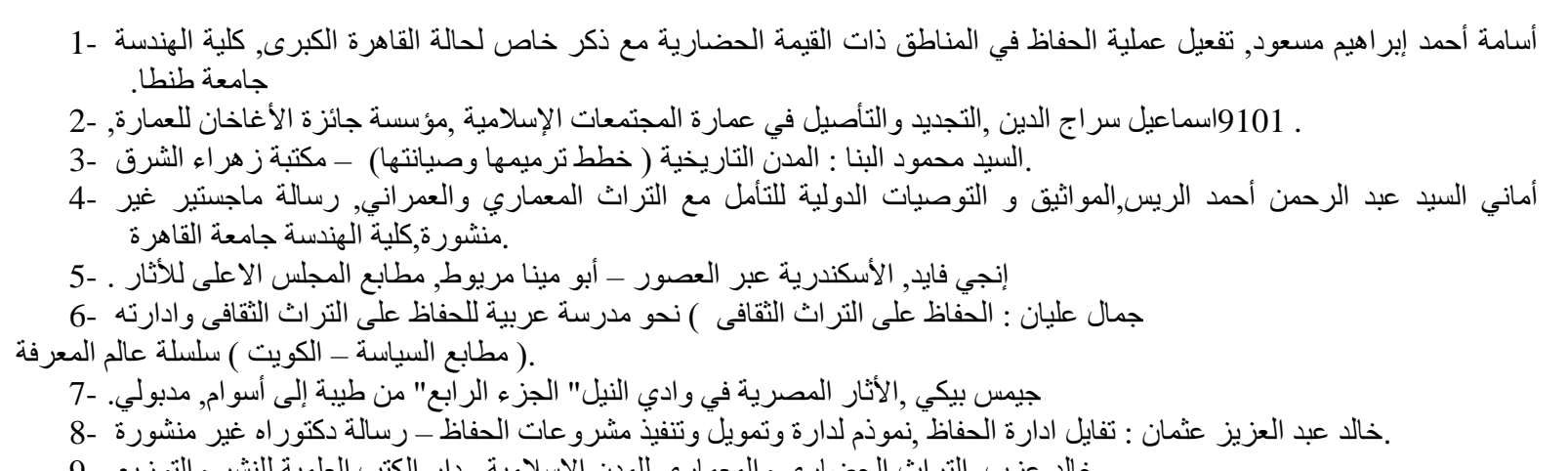

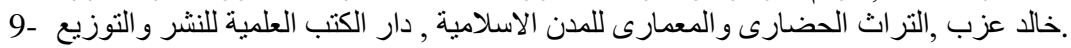

10- Ahmed Sedky, Living with heritage in Cairo, aucpress, 2009

11- Ash Amin, Nigel Thrift, CITIES Re imagining the Urban, Blackwell Publishers Ltd, 2002.

12- Arup research\& development, Maintain our heritage maintaining value, ove Arup\& partners Ltd, 2003.

13- Aylin Orbasli, Architectural conservation, Blackwell publishing,2008

14- Bernard M.Feilden, Jukka Jukilehto, Management guidelines for world culture heritage sites, ICCROM press, 1993.

15- Cairo governorate, ministry of culture, Reconsidering al-Fustat ( a trial to perceive Al- Fustat zone in a more appropriate \& beneficialway.supreme council of antiquities ,2006.

16- Cultnat, Ministry of communication and information technology, strategic approach to Egypt`s cultural Heritage, cultnat, 2001

17- Dietrich Wildung, Egypt From Prehistory to the Romans , taschen , 2009 edition

18- Doris Behrens- Abouseif, the Cairo Heritage, aucpress, 2000

19- Eleonore De Merode, Rieks Smeets,Carol Westrik,editors, Linking universal and local values "managing a sustainable future for world heritage" ,UNESCO,2004.

20- English heritage, Management of research projects in the historic environment, English heritage, 2005 .

21- Jamel Akbar,Crisis in the built environment "the case of muslim city", a miamat book,concept media ltd ,1988.

22- Jim Antoniou, Historic Cairo,a walk through the Islamic city, AUC press in Cairo,1998,Forth edition, 2006.

23- Jim Antoniou, Stephano Bianca, Sherif El-Hakim, Ronald Lewcock, Michael Welbank, The Conservation of the old City of Cairo, UNESCO,1980.

24- Jukka Jokilehto, What is OUV? Defining the outstanding universal value of cultural world heritage properties, published by hendrik Bäßbler verlag.Berlin,ICOMOS,2008

25- Mohamed H.Abdel Kader,Yasmine Sabry, Heritage Site Management in Egypt Tool for Local Development ", Engineering Research Journal ,Helwan University .

26- Mataria ,Volume 110,April 2007.

27- Selim Morcos,Nils Tongring, Youssef Halim, Mostafa El-Abbadi „Hassan Awad ,Towards integrated management of Alexandria coastal heritage,UNESCO,2003 . 
28- Stephano Bianca, Philip Jodidio ,editors, Cairo Revitalizing a historic metropolis ,the Aga khan trust for culture, 2006.

29- UNESCO, Basic text for the world Heritage convention 1972,.

30- UNESCO World Heritage Center, 2005.

31- UNESCO, Properties inscribed on the world heritage list, UNESCO, 2004.

32- UNESCO, Protect the under water cultural heritage, UNESCO celebration of 2002 .

33- united nations year for cultural heritage, 2002

Received: February 15, 2018

Accepted: April 20, 2018 